Article

\title{
Brand Equity and Usage Intention Powered by Value Co-Creation: A Case of Instagram in Kazakhstan
}

\author{
Dina Sadyk ${ }^{1}\left[\right.$ and Dewan Md Zahurul Islam ${ }^{2, *}$ \\ 1 The Department of Management and Marketing, Bang College of Business, KIMEP University, \\ Almaty 050010, Kazakhstan; Dina.Sadyk@kimep.kz \\ 2 Plymouth Business School, University of Plymouth, Drake Circus, Plymouth PL4 8AA, UK \\ * Correspondence: dewan.islam@plymouth.ac.uk
}

check for updates

Citation: Sadyk, D.; Islam, D.M.Z. Brand Equity and Usage Intention Powered by Value Co-Creation: A Case of Instagram in Kazakhstan. Sustainability 2022, 14, 500. https:// doi.org/10.3390/su14010500

Academic Editors: Gohar Khan,

Hangjung Zo and Feroz Abdul Karim

Received: 5 December 2021

Accepted: 30 December 2021

Published: 4 January 2022

Publisher's Note: MDPI stays neutral with regard to jurisdictional claims in published maps and institutional affiliations.

Copyright: (C) 2022 by the authors. Licensee MDPI, Basel, Switzerland. This article is an open access article distributed under the terms and conditions of the Creative Commons Attribution (CC BY) license (https:// creativecommons.org/licenses/by/ $4.0 /)$.

\begin{abstract}
Purpose: Unprecedented communication features of social media noticeably reinforce the active role of consumers in the value co-creation (VCC) of offline and online brands including social media. From the consumer perspective, this study examines a contribution of VCC behavior to consumer-based brand equity (CBBE) and consequent intention to use social media based on Instagram as the most popular platform in Kazakhstan. Methodology: A web-based survey provided data from 550 Instagram users in Almaty city. Empirical analysis includes testing statistical assumptions using SPSS 23, conducting confirmatory factor analysis (CFA), and structural equation modeling (SEM) using Warp PLS 7.0. Findings: With the result of this study investigation, the paper develops the model that explains the effect of VCC on continuous usage intention to use social media through CBBE comprising brand associations, brand loyalty and brand perceived quality. Originality: Even though the importance of social media in the brand VCC process is widely recognized, a brand equity view of social media brands with users' participation is under-investigated. However, brand equity's importance for firm sustainability in terms of long-term business strategy is indisputable. This research enhances brand equity theory and VCC concept with the empirical data within the modern social media context. Practical implications: Owners and managers of social media brands can use the conceptual model to grow, maintain and assess their brands' equities through their marketing efforts on the consumer motivation for brand VCC activities driving continuous usage of the brands.
\end{abstract}

Keywords: social media consumer-based brand equity; value co-creation; usage intention; brand loyalty; brand perceived quality

\section{Introduction}

Social media proven to be one of the most active online platforms worldwide with more than 3.6 billion users in 2020 anticipated to hit about 4.4 billion people in five years [1]. One of the outstanding features of social media is the unprecedented facilitation of peerto-peer communications and seller-buyer relationships, which is a part of a marketing strategy to meet the long-term brand objectives, including a vital target of higher consumer purchase intention [2]. Another significant utility of social media is the unique way to promote sustainable customer behavior through a sustainable business strategy $[3,4]$.

From the brand perspective, social media noticeably increase consumers' voice and power to influence the creation, promotion, and consumption of current brands activating customer participation in brands' value creation. Sales-Vivo et al. [5] demonstrate this role in the example of business-to-business activities, where value co-creation (VCC) is an essential antecedent of a manufacturer's economic satisfaction. Social media have become the integrative resource contributor to VCC on par with customers and firms reviving VCC theory born in the offline business era [6]. This study explores the impact of consumers' co-creation behavior on brand value building of social media as the modern digital media, which are widely used for achieving various business aims including sustainability as a growing prominent global trend. 
From the consumer perspective, the brand's size is measured with the customer-based brand equity (CBBE) that contributes to brand valuation [7]. So, in our research, we test $\mathrm{CBBE}$ as the main indicator of the effect of consumers' VCC behavior. Generally, CBBE is one of the most investigated areas for marketing scholars today provided more future research perspectives [8,9]. Social media enhance the CBBE concept as the role of social media in brand equity management is indisputable as virtual media have the power to strengthen or weaken a brand [10]. Apart from the significant impact on offline and online brands' equities, social media also noticeably contribute to own brand equities through their marketing activities [11]. One of the directions of contemporary brand equity theory is the social media contribution to firms marketing activities, e.g., many studies suggest modern actionable CBBE antecedents such as consumer engagement, electronic wordof-mouth (eWOM), and brand social value [12,13], which noticeably change consumer behavior [14,15]. Therefore, we observe the close interrelationships between social media and consumer VCC, social media, and brand equity. These interconnections open a new scholarly outlook to examine the convergence of the two significant theories, VCC and CBBE, on the social media crossroad.

This study attempts to answer the first question:

RQ1-Is there any relationship between VCC and CBBE of social media brands?

This paper also aims to explore a more comprehensive understanding of the effect of VCC and CBBE on consumers' behavior in terms of the social media brand's continuous usage intention. By doing so, this investigation intends to answer the second question:

RQ2-How consumers' VCC activities and created CBBE of social media affect consumers' usage intention of this social media?

Based on our literature review, the impact of consumer VCC behavior on social media CBBE and usage intention within one interrelationship model has not been examined yet. We propose a research model which explains the CBBE mediation effect of VCC on consumer intention to use social media on the example of Instagram in one of Kazakhstan cities. Kazakhstan is a favorable country for social media studies due to the continuously growing usage rate of around $26 \%$ for the last three years [16]. The findings develop VCC theory in the area of its role in brand equity building and extend previous CBBE research by showing that stronger brand equity delivers a greater usage intention effect in the contemporary digital media context.

\section{Literature Review}

\subsection{Value Co-Creation Theory in Social Media Context}

The dominant logic of economics has been shifting from product-domain to servicedomain logic of economy, e.g., from own authorship and offering ready physical goods to consumers to co-creation of ideas and products in close relationships with the customers [17]. Ritzer and Jurgenson [18] suggest the term prosumer to describe this new type of consumer. From the consumer perspective, cognition, emotion, and behavior are the experience-related factors within the VCC concept [19].

Social media contribute to the development of VCC theory by allowing people to interact with an audience of any size, obtaining value from creation and exchanging user-generated content asynchronously or in real-time based on Web 2.0 technological platforms [20,21]. These features considerably facilitate a turning consumers' role from passive receivers to active participants in the process of value creation almost everywhere, in the areas of goods and services innovations, in commercial and noncommercial spheres $[22,23]$. As the result, the prosumers co-create brand values within the social structures through the social processes that inevitably add a noticeable social character to the generated brands [24]. VCC philosophy transformed the brand from the marketing object to the social process due to the influential social aspect generated by the conversational area between the company and its different stakeholders throughout social media [25]. Thus, VCC is the joint activities of consumers' communities and companies, where each consumer 
is technologically enabled to contribute his knowledge and ideas in brand value creation, development, and maintenance [26].

Therefore, social media are the active co-creators of brand value [27]. Additionally, social media factors such as Web blogs and consumers' rating volume are more indicative and faster brand value metrics than the standard measures of online consumer behavior such as Web traffic and Internet searches [28]. However, a positive effect of social media marketing on the consumer in terms of his interaction with the brand in its VCC depends on the firm's capability to synchronize and integrate its own corporate processes and social media resources to deliver their messages to the target audience via appropriate social media channels, time, and occasions [29]. So, practitioners need deep insight into the mechanism of the interrelationship between the VCC process, brand value creation, and consumer behavioral outcomes such as purchase or usage intention.

Our literature review shows that the VCC area has been an actual research area for the last two decades. However, still, there is no consensus achieved on the critical aspects such as VCC scale and effects in the offline and online environment. Some studies focus on the behavioral facets of VCC, e.g., information seeking and sharing, helping, and tolerance [30]. Others measure VCC through the process dimensions such as interaction, experience, and relationships [31], or customer resources and motivation such as skills, creativity, and commitment [32]. Even so, most scholars consent to the significant role of social media, where consumer engagement has been powered in the VCC process. Various studies test distinct models of the relationship between consumer engagement and VCC in the virtual media context. Brodie et al. (2013) consider VCC as a subprocess of consumer engagement [33], while Cheung et al. (2020) propose consumer engagement as the main factor of augmenting consumer VCC and repurchase intentions [34]. So, consumers' VCC is an undisputable factor of brand value creation in the era of social media. We believe that the role of VCC needs to be further evaluated in terms of the direct effect on brand equity as the important elements of the brand valuation routine.

\subsection{Consumer-Based Brand Equity Theory}

CBBE is a strategic marketing concept that is mainly based on two different sciences such as information economics and cognitive psychology [8]. The former discipline is used to explain consumers' avoidance of uncertainty and wasting time on an information search when they choose reliable brands [35]. The latter science is used to disclose a mechanism of brand value building as the effect of consumer memory, perceptions, attitude, and attachment expressed in the CBBE dimensions of brand awareness, brand associations, a brand perceived quality, and brand loyalty, known as the sources of brand equity or the traditional CBBE scale elaborated by Aaker [7]. According to the author, the scale defines the consumer role in brand value creation as an intangible asset of a company. In other words, more positive consumer attitudes and stronger attachment to the brand ensure its greater value for the consumers and consequently for the firm in the long-term outlook. In more detail, brand awareness characterizes a potential buyer's ability to retrieve a particular brand's name and main features within a defined product category from his memory. The strength of the specific associations with the definite brand in the consumer memory shows the power of the brand differentiation among its competitors in the consumers' minds. A higher overall quality of the brand perceived or felt by customers versus alternatives contributes to the brand superiority versus analog products. A degree of brand loyalty among consumers allows assessment of the potential of future brand sales and profits due to its customers' preferences.

Marketers use CBBE as a general strategy to create and maintain powerful brands in delivering value to consumer and firm [36]. The robust CBBE contributes to the sustainable financial wellbeing of the firm; however, adequate marketing investments are required to build a strong brand [37]. Aaker's CBBE concept is widely recognized and used as the framework for numerous modern marketing studies [38-40], which are very useful for marketers in terms of the proven mechanisms of CBBE creation through the current multi- 
channel environment. Some scholars apply brand awareness and brand associations linked to the consumers' memory within one factor named brand awareness/associations $[39,40]$.

\section{Hypotheses Development}

\subsection{Effect of User Value Co-Creation Behavior on Social Media Consumer-Based Brand Equity}

This study applies VCC logic considering the active consumer role in co-creation of brand value, which can be assessed through CBBE. The importance of social media marketing activities on CBBE of offline and online brands is indisputable [41]. Apart from the significant positive impact on the brand equity of various brands, social media also noticeably contribute to own brand equity through own online marketing activities [11]. Social media makes the co-creation process more effective due to providing an engaging platform for the customer to contribute to brand equity building [42]. Thereby, we examine consumers and social media as active contributors to brand equity creation due to a direct and easy bottom-up communication flow 24/7 from consumers to producers [43].

Extant social media studies are based on VCC theory to clarify the role of social media in the VCC process [44] or even describe the process in steps [23]. Some papers demonstrate the relationship between brand equity and VCC in an offline context $[45,46]$. Theoretical research of Rubio et al. [47] emphasizes a prominent role of VCC in brand equity management in the era of marketing 4.0 when virtual communities are the great reliable source of big data about real consumer voice to analyze. One of the key questions here is to define what kind of big data should be collected for the analysis. In other words, marketers need to operate with the factually proven relationship model of brand equity creation reinforced by users' VCC behavior in social media.

We found that extant literature can be advanced with the empirical testing of consumer VCC effect on CBBE of social media per se to develop further VCC concepts and CBBE theory, which converge on the social media platform. We assume that social media users can augment brand equity through their VCC activities and hypothesize a relationship between users' VCC behavior and CBBE building. We suppose that the effect is conditioned by the extraordinary features of social media, which allow horizontal peer-to-peer and upward consumers-to-business communications to be global, instant, easy, and mobile regardless of users' locations and time zones. Consequently, the customers have more opportunities and power to participate directly in many brands' values building through their activities in various online communities. We test the hypothesized effect of VCC behavior on CBBE on the most popular social media in Kazakhstan.

\section{Hypothesis 1. User VCC behavior has a positive effect on SM CBBE.}

\subsection{Usage Intention as an Outcome of Social Media Consumer-Based Brand Equity}

Many scholars explore the consumer behavior as a result of brand equity building for offline and online brands for the last decade. One of the most analyzed results of CBBE in the reviewed literature is the purchase intention of consumers acting in an online environment and social media [48-51]. Many scholars suggest brand purchase intention as one of the most essential outcomes of CBBE due to social media marketing activities [52-54]. Numerous investigations in social media demonstrate the influence of brand equity on customers' behavior in various business types from consumer commitment in the airline industry [55] to repeated purchases in the bank industry [56].

Since most social media services are nonpaid, intention to use rather than purchase was chosen to analyze social media brands per se in this study. However, the influence of SM CBBE on the usage intention of social media brands is under-investigated in the extant research base. Thus, we aim to enhance our research model with the hypothesized effect of SM CBBE on consumers' intention to continuously use social media.

Hypothesis 2. SM CBBE has a positive effect on SM usage intention. 
Figure 1 depicts the proposed research model of influence of user VCC behavior on SM CBBE and usage intention.

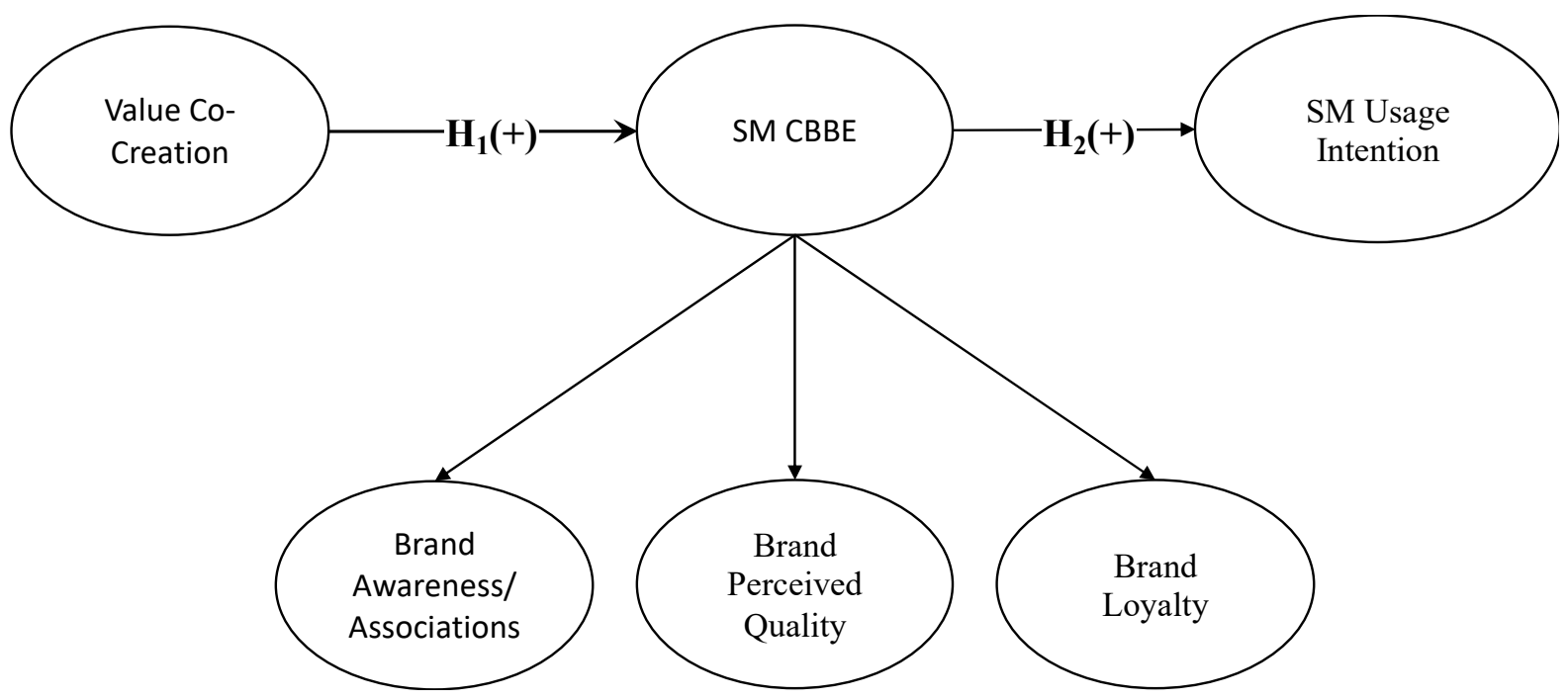

Figure 1. Research model.

\section{Research Methodology}

We involved 7 marketing managers and directors from various industries, who use Instagram, as well as other 11 nonmarketing Instagram users in the study discussions on the stage of our research conceptualization to reveal the actuality and practical significance of the planned investigation. We collected primary data by applying a self-administered Web-based questionnaire to scrutinize the proposed model through the PLS-SEM method.

\subsection{Data Collection}

Instagram is the most popular social media in Kazakhstan. According to the "Digital 2021: Kazakhstan" report [16], Instagram has the largest number of users in Kazakhstan among social media, which is 11 million people or $58.2 \%$ of the total population who can be reached through advertising on this platform. Moreover, Instagram's advertising reach is $78.7 \%$ among those aged 13 and older, with an average quarterly growth rate of $10 \%$.

Five hundred and fifty Instagram users aged 18 and older have filled in questionnaires on the survio.com platform between 19 September to 18 October 2020, in Almaty city. We used a sampling approach to reflect the age and gender structure of Instagram users in the country. According to the survey data from ACT Kazakhstan (2017) about social media usage, the biggest age group is 18-29 years old (62\%), the second group is 30-40 years old ( $26 \%)$, and the smallest is $41-55$ years old (12\%) among Instagram users. The agency reported the gender split as $58 / 42 \%$ of female/male among Instagram users in the country. Survio is survey software that is easy for respondents to use due to its friendly interface and availability on all digital devices. Table 1 shows the demographic profile and social media usage behavior characteristics of the respondents.

Questions asked of respondents included age, gender, education, and social media usage behavior to get local users' profiles. Items to measure the model variables were adapted from the relevant studies in the areas of SM CBBE [39], VCC [34], and usage intention [57] in the social media context.

A six-level Likert scale consists of scores from 1 (one) to 6 (six) such as "strongly disagree 1, disagree 2, partly disagree 3, partly agree 4, agree 5, and strongly agree 6". A 6-level Likert scale is used in many contemporary studies to measure human behavioral aspects, for example, consumer studies [58], social research [59], medical investigations [60,61], politics [62], and social media $[63,64]$. 
Table 1. Profiles of respondents.

\begin{tabular}{|c|c|c|}
\hline Variable & Value & $\mathbf{N}(\%)$ \\
\hline \multirow{2}{*}{ Gender } & Female & $328(59.6)$ \\
\hline & Male & $222(40.4)$ \\
\hline \multirow{4}{*}{ Age } & $18-24$ & $234(42.5)$ \\
\hline & $25-34$ & $184(33.5)$ \\
\hline & $35-54$ & $126(22.9)$ \\
\hline & $55-64$ & $6(1.1)$ \\
\hline \multirow{4}{*}{ Education } & High-school graduates & $48(8.7)$ \\
\hline & College graduates & $95(17.3)$ \\
\hline & University graduates & $281(51.1)$ \\
\hline & Postgraduates & $126(22.9)$ \\
\hline \multirow{3}{*}{ Social Media Usage Frequency } & $1-5$ times per day & $308(56.0)$ \\
\hline & 6-10 times per day & $159(28.9)$ \\
\hline & More than 10 times per day & $83(15.1)$ \\
\hline \multirow{5}{*}{ Social Media Usage Time } & Less than $1 \mathrm{~h}$ per day & $114(20.7)$ \\
\hline & $1-2 \mathrm{~h}$ per day & $208(37.8)$ \\
\hline & $3-4 \mathrm{~h}$ per day & $154(28.0)$ \\
\hline & $5-6 \mathrm{~h}$ per day & $47(8.5)$ \\
\hline & More than $6 \mathrm{~h}$ per day & $27(4.9)$ \\
\hline \multirow{5}{*}{ Social Media Usage Duration } & Less than 5 min per visit & $115(20.9)$ \\
\hline & About 15 min per visit & $233(42.4)$ \\
\hline & About 30 min per visit & $124(22.5)$ \\
\hline & About $1 \mathrm{~h}$ per visit & $44(8.0)$ \\
\hline & More than $1 \mathrm{~h}$ per visit & $34(6.2)$ \\
\hline
\end{tabular}

\subsection{Questionnaire}

Some experts [65] opine that the neutral point "neither agree nor disagree" is recommended to be included. However, other scholars argue that an absence of the neutral point does not significantly impact reliability, correlations, and factor loadings of research data [66]. Additionally, during our prior surveys, we noticed that local people frequently abuse neutral responses, which negatively affected the quality of gathered data. So, we excluded the neutral point in the Likert scale to get differential attitudes and behavior of social media users.

We involved the local translator agency in the procedures of translation and backtranslation. The elaborated Russian version of the questionnaire is equivalent to the original English form and understandable for local respondents. Further, we addressed a concern about common method bias as our survey has a self-administered nature. We divided the questionnaire into sections using headings as short descriptions to introduce the meaning of each section. We placed the sections with the dependent variables and key antecedents furthest from each other and in reverse sequence to minimize a potential effect of predictability of casual association between factors and output. For example, the section of usage intention and CBBE dimensions are well separated, the sections of CBBE dimensions are located before VCC. A short introduction ensures the confidentiality and anonymity of the survey respondents to get more sincere and honest answers from consumers.

\section{Data Analysis}

Residual statistics, including Mahalanobis distance, were calculated, and 11 outliers with the extreme values of the distance above 140.325 and below 9.450 were detected and excluded from further analysis. Collinearity diagnostic was used to check correlations between independent variables. No serious multicollinearity was revealed for all items, which had variance inflation factor (VIF) values much below 10, which correspond to a tolerance cut-off level of 0.1 [67]. The homoscedasticity assumption was tested through 
the graph with ZPRED on $X$-axis and ZRESID on $Y$-axis. No sharp turn was detected on the Locally Weighted Scatterplot Smoothing (LOWESS), or more frequently called a LOESS (locally weighted smoothing) fit line. Thus, homoscedasticity was established as the visual test showed the equal distribution of error terms across all values of the independent variables [68].

\subsection{Descriptive Statistics}

All the independent variables met the data variance assumptions as all the variance numbers were below 10, as generally recommended by literature [68]. The independent variables were checked for univariate normality using recommended values range between -1.000 and 1.000 for skewness, and between -2.000 and 2.000 for kurtosis [69]. Three brand-awareness items and one VCC item were excluded from further statistical tests due to the skewness and kurtosis numbers above the applied thresholds. However, the significance was 1.000 for both tests such as Kolmogorov-Smirnov and Shapiro-Wilson tests for all the items that were below the recommended 0.05 to reject a null hypothesis and recognize the non-normal distribution of the means of the data across the sample [70]. Considering the non-normal distribution of the data, the model structure was analyzed with Warp PLS 7.0 as the PLS approach does not require multivariate normality [71] having the nonlinear analysis algorithms [72].

\subsection{Reliability and Validity}

Loadings of the indicators to the factors are sufficient as above 0.7 and significant [68]. The constructs are internally consistent due to CR and Cronbach's alpha values above the recommended threshold of $0.7[73,74]$. Convergent validity was also established with an AVE of more than 0.6 for all the constructs, whereas a minimum level is 0.5 is required [68]. All the values for the items and constructs as the first-order dimensions are shown in Table 2.

The higher-order construct of CBBE was significantly measured by the first-order dimensions of brand associations $(\beta=0.870$ per cent Confidence Interval, $C I=0.793-0.946$, $p<0.01$ ), brand loyalty $(\beta=0.876$, per cent $C I=0.799-0.952, p<0.01)$, perceived quality $(\beta=0.870$, per cent $C I=0.794-0.946, p<0.01)$.

Discriminant validity was established as all squared roots of AVEs for all the constructs on diagonal are higher than any other correlations among all latent variables. Table 3 shows that all the correlations and squared roots of AVEs are significant with a $p$-value less than 0.001 .

Overall, we observe the acceptable validation of our study's constructs.

\subsection{Common Method Bias}

We observe no common method bias using Harman's single factor test and full collinearity test. Average variance extracted (AVE) is equal to 0.418 for the Harman's marker variable that is less than threshold of 0.5 , and full collinearity variance inflation factors (FCVIF) less than accepTable $3.3(\mathrm{VCC}=1.208, \mathrm{UI}=1.773, \mathrm{CBBE}=1.839)$ [75].

\subsection{Model Fit}

All indicators satisfy the model fit requirements including average full collinearity VIF of 1.928 that is below 5.0 and high Tenenhaus goodness of fit of 0.393 that is above 0.36 as recommended in the literature [68]. Other indicators of the good model fit are represented in Table 4. 
Table 2. Results of the confirmatory factor analysis (CFA) for the research model.

\begin{tabular}{|c|c|c|c|c|}
\hline \multirow[t]{2}{*}{ Factors and ITEMS } & \multirow{2}{*}{$\begin{array}{c}\text { Convergent Validity } \\
\text { WarpPLS Std. Loadings (t-Value) }\end{array}$} & \multicolumn{3}{|c|}{ Reliability } \\
\hline & & $\mathrm{C} \alpha$ & $\mathrm{CO}$ & AVE \\
\hline Brand Perceived Quality & & 0.834 & 0.901 & 0.752 \\
\hline BPQ1 Instagram provides quality services. & $0.838^{* * *}(21.464)$ & & & \\
\hline $\begin{array}{l}\text { BPQ2 Compared to other social media, Instagram has } \\
\text { a very high quality of service. }\end{array}$ & $0.895 * * *(23.086)$ & & & \\
\hline BPQ3 Instagram has great features. & $0.866^{* * *}(22.262)$ & & & \\
\hline Brand Loyalty & & 0.844 & 0.906 & 0.762 \\
\hline BLY1 I consider myself a loyal Instagram user. & $0.865 * * *(22.231)$ & & & \\
\hline BLY2 Instagram is my first choice for social media. & $0.859^{* * *}(22.043)$ & & & \\
\hline BLY3 I will be a loyal Instagram user in the future. & $0.894^{* * *}(23.050)$ & & & \\
\hline Brand Associations & & 0.770 & 0.868 & 0.687 \\
\hline BAS1 Instagram gives me special associations. & $0.833^{* * *}(21.325)$ & & & \\
\hline BAS2 Instagram gives me favorable associations. & $0.883^{* * *}(22.721)$ & & & \\
\hline BAS3 I have a clear understanding of Instagram. & $0.767 * * *(19.479)$ & & & \\
\hline Value Co-Creation & & 0.845 & 0.907 & 0.764 \\
\hline $\begin{array}{l}\text { VCC4 If I have any problems using Instagram, I } \\
\text { inform the administration of the application about it. }\end{array}$ & $0.851^{* * *}(21.824)$ & & & \\
\hline $\begin{array}{l}\text { VCC5 When I have a useful idea to improve } \\
\text { Instagram services, I inform the administration of the } \\
\text { application about it. }\end{array}$ & $0.909 * * *(23.467)$ & & & \\
\hline $\begin{array}{l}\text { VCC6 The Instagram administration encourages } \\
\text { users to participate in the creation of new services. }\end{array}$ & $0.861 * * *(22.116)$ & & & \\
\hline Usage Intention & & 0.838 & 0.903 & 0.755 \\
\hline $\begin{array}{l}\text { UI1 I think that more and more people will use } \\
\text { Instagram in the future. }\end{array}$ & $0.831 * * *(21.268)$ & & & \\
\hline UI2 I am sure that I will use Instagram in the future. & $0.897^{* * *}(23.118)$ & & & \\
\hline $\begin{array}{l}\text { UI3 I will recommend to my friends and } \\
\text { acquaintances to use Instagram and contribute to its } \\
\text { development. }\end{array}$ & $0.878^{* * *}(22.604)$ & & & \\
\hline
\end{tabular}

Note: $\mathrm{BPQ}=$ brand perceived quality; $\mathrm{BLY}=$ brand loyalty; $\mathrm{BAS}=$ brand associations; $\mathrm{VCC}=$ value co-creation $\mathrm{UI}=$ usage intention; $\mathrm{C} \alpha=$ Cronbach's $\alpha ; \mathrm{CO}=$ composite $\alpha ; \mathrm{AVE}=$ average variance extracted; ${ }^{* * *}=p \leq 0.001$.

Table 3. Discriminant validity test.

\begin{tabular}{cccc}
\hline \multirow{2}{*}{ Constructs } & \multicolumn{3}{c}{ Factor Correlations } \\
\cline { 2 - 4 } & $\mathbf{( 1 )}$ & $\mathbf{( 2 )}$ & (3) \\
\hline (1) CBBE & $\mathbf{0 . 8 7 2 ^ { * * * }}$ & \\
\hline (2) VCC & $0.396^{* * *}$ & $\mathbf{0 . 8 7 4 ^ { * * * }}$ \\
\hline (3) UI & $0.652^{* * *}$ & $0.353^{* * *}$ & $\mathbf{0 . 8 6 9 ^ { * * * }}$ \\
\hline
\end{tabular}

Note: Diagonal bold numbers signify the square roots of the AVEs; ${ }^{* * *}=p \leq 0.001$. 
Table 4. Validation criteria for a PLS-SEM model.

\begin{tabular}{|c|c|c|c|c|c|c|}
\hline Indices & Interpretation & Size & Recommended Level & Hypothesized Model & & \\
\hline & & & & Endogenous Factors & $\mathbf{R}^{2}$ & AVE \\
\hline \multirow{4}{*}{$f^{2}$} & \multirow{4}{*}{ Effect of size for $\mathrm{R}^{2}$} & Small & 0.02 & & & \\
\hline & & Medium & 0.15 & & & \\
\hline & & Large & 0.35 & CBBE & 0.158 & 0.760 \\
\hline & & & & Usage Intention & 0.442 & 0.755 \\
\hline \multirow{4}{*}{ GoF } & \multirow{3}{*}{ Goodness-of-Fit } & Small & 0.10 & & & \\
\hline & & Medium & 0.25 & & & \\
\hline & & Large & 0.36 & & & \\
\hline & & & & Average & 0.3 & 0.758 \\
\hline \multicolumn{2}{|c|}{$f^{2}=\overline{R^{2}} \div\left(1-\overline{R^{2}}\right)$} & Small-medium & & & \multicolumn{2}{|c|}{$f^{2}=0.099$} \\
\hline \multicolumn{2}{|c|}{$G o F=\sqrt{\overline{A V E} \times \overline{R^{2}}}$} & Medium & & & \multicolumn{2}{|c|}{$\mathrm{GoF}=0.261$} \\
\hline
\end{tabular}

\subsection{Structural Equation Modeling (SEM)}

Except for the effect of brand associations on usage intention, all other relations' betacoefficients are significant $(p$-value $<0.001$ ) and range from 0.312 to 0.411 , which confirm extant theories and the reviewed results from prior studies on usage intention result from SM CBBE measures such as brand perceived quality and brand loyalty in a social media context. Path coefficients demonstrate relationships among factors within the research model as shown in Table 5.

Table 5. Results of the hypothesized model and $\beta$ coefficients tests.

\begin{tabular}{cccccc}
\hline Hyp. & Paths & $\begin{array}{c}\beta \text { Coefficients } \\
\text { (Std. Error) }\end{array}$ & t-Value & Effect Size & Test Results \\
\hline H1 & Value Co-creation $\rightarrow$ CBBE & $0.40^{* * *}(0.041)$ & 9.661 & 0.158 & Supported \\
H2 & CBBE $\rightarrow$ Usage Intention & $0.60^{* * *}(0.040)$ & 14.989 & 0.393 & Supported \\
\hline
\end{tabular}

$$
{ }^{* * *}=p \leq 0.001 \text {. }
$$

\subsection{Mediation Analysis}

Sobel test and path analysis confirm mediating effects of brand perceived quality and brand loyalty in the contribution of social media users' VCC behavior to their usage intention. Z-values for both impacts are above 8.178 and statistically significant that confirms the importance of existing indirect effects [76] as depicted on Table 6.

Table 6. Mediation test results.

\begin{tabular}{|c|c|c|c|}
\hline Construct & Construct Relationship & t-Value of Path Coefficient & Sobel Test's z-Value \\
\hline $\mathrm{VCC} \rightarrow \mathrm{BPQ} \rightarrow \mathrm{UI}$ & $\begin{array}{c}\mathrm{VCC} \rightarrow \mathrm{CBBE} \\
\mathrm{CBBE} \rightarrow \mathrm{UI}\end{array}$ & $\begin{array}{c}9.661 \\
14.989\end{array}$ & $8.178^{* * *}$ \\
\hline
\end{tabular}

\section{Discussion}

Although social media energized the co-creation role of consumers in brand value building, the VCC concept is under-investigated in the context of virtual communications [77]. This study explains the effect of user VCC behavior on SM CBBE via its three dimensions, comprising brand associations, brand perceived quality, and brand loyalty. Thus, the analyzed impact demonstrates that social media and an activated VCC process is beneficial not only for offline and online brands, as explored in numerous extant studies, but also for social media brands, whose users are active participants in co-creation of the brand equity of social media that they utilize through online activities. These results 
confirm that CBBE is an outcome of accumulated power of the strong relationship between brand and customers [78] for social media brands as well as for traditional and other virtual brands. Thus, the VCC process reinforced by social media [79] is critical for social media per se in terms of brand equity building and maintenance.

Furthermore, these research findings suggest that social media usage intention is an output of SM CBBE. So, users' perception of the higher quality of social media brand, their positive associations with the brand, and stronger attachment to it may augment the behavioral intention to use social media. These results confirm the positive impact of CBBE on usage intention for offline brands presented in extant literature. Likewise, our study extends empirical observations of CBBE's favorable effect on consumers' intention to use social media brands.

Overall, the research model demonstrates an active role of users in the co-creation of brand equity of social media brands. Their networking activities contribute to the higher brand quality, positive associations with the brand, and stronger brand loyalty, which are the reasons for the continued usage of social media.

\section{Conclusions}

Despite the growing role of social media in strategic brand management, there is a gap in extant empirical research on VCC input to $\mathrm{CBBE}$ and the usage intention of social media brands. Most prior studies suggest consumers' VCC measurement and process for offline and virtual brands [19,32,34]. Our study extends the available research with the evaluation of users' VCC effect on equity creation of social media brands. Our view is based on observing close interconnections between VCC and social media [23,42] and social media and CBBE $[39,40]$ in the era of growing importance of the virtual environment. As a result, the positive effect of consumers' VCC behavior on SM CBBE building is empirically proven on the example of Instagram.

Further, we test usage intention as one of the important behavioral outputs of CBBE explored in existing literature $[52,80]$ and confirm this effect for social media brands in the conditions of the users' VCC behavior. Hence, this study contributes to the CBBE concept and VCC theory with the advanced empirical data on the interrelationship among VCC, brand equity, and usage intention of social media brands.

Practitioners can use the proposed model to measure brand equity of social media, evaluate consumer participation in brand value creation, and degree of intention to use the media. Marketers can stimulate users' activities in the brand value-building process, focusing on forming positive associations of the brand among the consumers, growing their loyalty and brand's quality perception, which helps to increase intention to use social media.

This research is limited to one city and one social media platform. Future studies may cover various locations and other social media brands to clarify and generalize the suggested model of the VCC effect on SM CBBE and usage intention. Moreover, the prospect research may test the effectiveness of exploitation of social media for the impact on business sustainability through the proposed users' value co-creation model of digital media.

Author Contributions: Conceptualization, methodology, D.S. and D.M.Z.I.; data collection, analysis, writing, D.S.; supervision, review, editing, D.M.Z.I. All authors have read and agreed to the published version of the manuscript.

Funding: This research received no external funding.

Institutional Review Board Statement: Not applicable.

Informed Consent Statement: Not applicable.

Data Availability Statement: The data are available in excel format upon request or online https: / / my.survio.com/U8B9T9G5A7G7A1O9R1M6/results, accessed on 22 December 2021.

Conflicts of Interest: The authors declare no conflict of interest. 


\section{References}

1. Statista. Number of social Network Users Worldwide from 2017 to 2025. Available online: https:/ / www.statista.com/statistics / 278414/number-of-worldwide-social-network-users/ (accessed on 17 September 2021).

2. Wibowo, A.; Chen, S.-H.; Wiangin, U.; Ma, Y.; Ruangkanjanases, A. Customer Behavior as an Outcome of Social Media Marketing: The Role of Social Media Marketing Activity and Customer Experience. Sustainability 2021, 13, 189. [CrossRef]

3. Joo, Y.; Seok, H.; Nam, Y. The Moderating Effect of Social Media Use on Sustainable Rural Tourism: A Theory of Planned Behavior Model. Sustainability 2020, 12, 4095. [CrossRef]

4. Ho, C.-W.; Wang, Y.-B. Does Social Media Marketing and Brand Community Play the Role in Building a Sustainable Digital Business Strategy. Sustainability 2020, 12, 6417. [CrossRef]

5. Sales-Vivó, V.; Gil-Saura, I.; Gallarza, M.G. Value Co-Creation and Satisfaction in B2B Context: A Triadic Study in the Furniture Industry. Sustainability 2021, 13, 152. [CrossRef]

6. Singaraju, S.P.; Nguyen, Q.A.; Niininen, O.; Sullivan-Mort, G. Social Media and Value Co-Creation in Multi-Stakeholder Systems: A Resource Integration Approach. Ind. Mark. Manag. 2016, 54, 44-55. [CrossRef]

7. Aaker, D. Managing Brand Equity: Capitalizing on the Value of a Brand Name; Free Press: New York, NY, USA, 1991.

8. Christodoulides, G.; Chernatony, L. Consumer Based Brand Equity Conceptualization \& Measurement: A Literature Review. Int. J. Mark. Res. 2010, 52, 43-66. [CrossRef]

9. Baalbaki, S.; Guzman, F. A Consumer-perceived Consumer-based Brand Equity Scale. J. Brand Manag. 2016, $23,229-251$. [CrossRef]

10. Kohli, C.; Suri, R.; Kapoor, A. Will Social Media Kill Branding? Bus. Horiz. 2015, 58, 35-44. [CrossRef]

11. Kavisekera, S.; Abeysekera, N. Effect of Social Media Marketing on Brand Equity of Online Companies. J. Mark. Manag. 2016, 14, 201-216.

12. Godey, B.; Manthiou, A.; Pederzoli, D.; Rokka, J.; Aiello, G.; Donvito, R.; Singh, R. Social Media Marketing Efforts of Luxury Brands: Influence on Brand Equity and Consumer Behavior. J. Bus. Res. 2016, 69, 5833-5841. [CrossRef]

13. Bruhn, M.; Schoenmueller, V.; Schäfer, D.B. Are Social Media Replacing Traditional Media in Terms of Brand Equity Creation? Manag. Res. Rev. 2012, 35, 770-790. [CrossRef]

14. Koay, K.Y.; Ong, D.L.T.; Khoo, K.L.; Yeoh, H.J. Perceived Social Media Marketing Activities and Consumer-Based Brand Equity: Testing a Moderated Mediation Model. Asia Pac. J. Mark. Logist. 2020, 33, 53-72. [CrossRef]

15. Kim, A.J.; Ko, E. Do Social Media Marketing Activities Enhance Customer Equity? An Empirical Study of Luxury Fashion Brand. J. Bus. Res. 2012, 65, 1480-1486. [CrossRef]

16. Kemp, S. Digital 2020: Kazakhstan, Datareportal. Available online: https:/ / datareportal.com/reports/digital-2020-kazakhstan (accessed on 5 January 2020).

17. Vargo, S.L.; Lusch, R.F. Evolving to a New Dominant Logic for Marketing. J. Mark. 2004, 68, 1-17. [CrossRef]

18. Ritzer, G.; Jurgenson, N. Production, Consumption, Prosumption: The Nature of Capitalism in the Age of the Digital "Prosumer". J. Consum. Cult. 2010, 10, 13-36. [CrossRef]

19. Payne, A.F.; Storbacka, K.; Frow, P. Managing the Co-Creation of Value. Acad. Mark. Sci. Rev. 2008, 36, 83-96. [CrossRef]

20. Kaplan, A.M.; Haenlein, M. Users of the World, Unite! The Challenges and Opportunities of Social Media. Bus. Horiz. 2010, 53, 59-68. [CrossRef]

21. Carr, C.T.; Hayes, R.A. Social Media: Defining, Developing, and Divining. Atl. J. Commun. 2015, 23, 46-65. [CrossRef]

22. Piller, F.; Vossen, A.; Ihl, C. From Social Media to Social Product Development: The Impact of Social Media on Co-Creation of Innovation. Die Unternehm. 2012, 66, 7-27. [CrossRef]

23. Kao, T.-Y.; Yang, M.-H.; Wu, J.-T.B.; Cheng, Y.-Y. Co-Creating Value with Consumers through Social Media. J. Serv. Mark. 2016, 30, 141-151. [CrossRef]

24. Edvardsson, B.; Tronvoll, B.; Gruber, T. Expanding Understanding of Service Exchange and Value Co-Creation: A Social Construction Approach. Acad. Mark. Sci. Rev. 2010, 39, 327-339. [CrossRef]

25. Iglesias, O.; Ind, N.; Alfaro, M. The Organic View of the Brand: A Brand Value Co-Creation. J. Brand Manag. 2013, 20, 670-688. [CrossRef]

26. Prahalad, C.K.; Ramaswamy, V. Co-creating Unique Value with Customers. Strategy Leadersh. 2004, 32, 4-9. [CrossRef]

27. Tajvidi, M.; Richard, M.O.; Wang, Y.; Hajli, N. Brand Co-Creation through Social Commerce Information Sharing: The Role of Social Media. J. Bus. Res. 2020, 121, 476-486. [CrossRef]

28. Luo, X.; Zhang, J.; Duan, W. Social Media and Firm Equity Value. Inf. Syst. Res. 2013, 24, 146-163. [CrossRef]

29. Sorensen, A.; Andrews, L.; Drennan, J. Using Social Media Posts as Resources for Engaging in Value Co-Creation: The Case for Social Media-Based Cause Brand Communities. J. Serv. Theory Pract. 2017, 27, 898-922. [CrossRef]

30. Yi, Y.; Gong, T. Customer value co-creation behavior: Scale development and validation. J. Bus. Res. 2012, 66, 1279-1284. [CrossRef]

31. Ranjan, K.R.; Read, S. Value Co-Creation: Concept and Measurement. Acad. Mark. Sci. Rev. 2016, 44, 290-315. [CrossRef]

32. Merz, M.A.; Zarantonello, L.; Grappi, S. How Valuable Are Your Customers in the Brand Value Co-Creation Process? The Development of a Customer Co-Creation Value (CCCV) Scale. J. Bus. Res. 2018, 82, 79-89. [CrossRef]

33. Brodie, R.J.; Ilic, A.; Juric, B.; Hollebeek, L. Consumer Engagement in a Virtual Brand Community: An Exploratory Analysis. J. Bus. Res. 2013, 66, 105-114. [CrossRef] 
34. Cheung, M.L.; Pires, G.D.; Rosenberger, P.J.; Oliveira, M.J.D. Driving Consumer-Brand Engagement and Co-Creation by Brand Interactivity. Mark. Intell. Plan. 2020, 38, 523-541. [CrossRef]

35. Erdem, T.; Swait, J.; Valenzuela, A. Brands as Signals: A Cross-Country Validation Study. J. Mark. 2006, 70, 34-49. [CrossRef]

36. Saputra, D.; Indarini, I.; Margaretha, S. The Effect of Consumer-Based Brand Equity on Customer Satisfaction and Brand Loyalty in the Coffee Bean \& Tea Leaf or Maxx Coffee. Adv. Econ. Bus. Manag. Res. 2020, 115, 293-298. [CrossRef]

37. Fischer, M.; Himme, A. The Financial Brand Value Chain: How Brand Investments Contribute to the Financial Health of Firms. Int. J. Res. Mark. 2017, 34, 137-153. [CrossRef]

38. Hyun, M.Y.; Kim, H.-C. Refinement and Validation of a Multidimensional Destination Brand Equity Scale for Inbound and Outbound Chinese Travelers: A Cross-National Perspective. J. Travel Res. 2020, 59, 1522-1552. [CrossRef]

39. Dwivedi, A.; Johnson, L.W.; Wilkie, D.C.; De Araujo-Gil, L. Consumer Emotional Brand Attachment with Social Media Brands and Social Media Brand Equity. Eur. J. Mark. 2019, 53, 1176-1204. [CrossRef]

40. Algharabat, R.; Rana, N.P.; Alalwan, A.A.; Baabdullah, A.; Gupta, A. Investigating the antecedents of customer brand engagement and consumer-based brand equity in social media. J. Retail. Consum. Serv. 2020, 53, 101767. [CrossRef]

41. Zollo, L.; Filieri, R.; Rialti, R.; Yoon, S. Unpacking the Relationship between Social Media Marketing and Brand Equity: The Mediating Role of Consumers' Benefits and Experience. J. Bus. Res. 2020, 117, 256-267. [CrossRef]

42. Ramaswamy, V.; Ozcan, K. Brand Value Co-Creation in a Digitalized World: An Integrative Framework and Research Implications. Int. J. Res. Mark. 2016, 33, 93-106. [CrossRef]

43. Bruns, A. From prosumption to produsage. In Handbook on the Digital Creative Economy; Towse, R., Handke, C., Eds.; Edward Elgar Publishing: Cheltenham, UK, 2013; pp. 67-78. [CrossRef]

44. Rashid, Y.; Waseem, A.; Akbar, A.A.; Azam, F. Value Co-Creation and Social Media: A Systematic Literature Review Using Citation and Thematic Analysis. Eur. Bus. Rev. 2019, 31, 761-784. [CrossRef]

45. Moise, M.S.; Gil-Saura, I.; Ruiz-Molina, M.-E. Implications of Value Co-Creation in Green Hotels: The Moderating Effect of Trip Purpose and Generational Cohort. Sustainability 2020, 12, 9866. [CrossRef]

46. Omar, N.A.; Kassim, A.S.; Shah, N.U.; Alam, S.S.; Wel, C.A.C. The Influence of Customer Value Co-Creation Behavior on SME Brand Equity: An Empirical Analysis. Iran. J. Manag. Stud. 2020, 13, 165-196. [CrossRef]

47. Rubio, N.; Villaseñor, N.; Yagüe, M.J. Value Co-Creation in Third-Party Managed Virtual Communities and Brand Equity. Front. Psychol. 2020, 11, 927. [CrossRef]

48. Coursaris, C.K.; Osch, W.; Balogh, B.A. Do Facebook Likes Lead to Shares or Sales? Exploring the Empirical Links between Social Media Content, Brand Equity, Purchase Intention, and Engagement. In Proceedings of the 49th Hawaii International Conference on System Sciences (HICSS), Koloa, HI, USA, 5-8 January 2016; pp. 3546-3555. [CrossRef]

49. Le, L.T.; Tran, L.T.T.; Pham, L.M.T.; Tran, D.T.D. A Revised Model of E-Brand Equity and Its Application to High Technology Products. J. High Technol. Manag. Res. 2018, 29, 151-160. [CrossRef]

50. Dehghani, M.; Tumer, M. A Research on Effectiveness of Facebook Advertising on Enhancing Purchase Intention of Consumers. Comput. Hum. Behav. 2015, 49, 597-600. [CrossRef]

51. Poturak, M.; Softić, S. Influence of Social Media Content on Consumer Purchase Intention: Mediation Effect of Brand Equity EJBE 2019, 12, 17-43. [CrossRef]

52. Choedon, T.; Lee, Y.-C. The Effect of Social Media Marketing Activities on Purchase Intention with Brand Equity and Social Brand Engagement: Empirical Evidence from Korean Cosmetic Firms. Knowl. Manag. Res. 2020, 21, 141-160. [CrossRef]

53. Hasim, M.A.; Shahrin, M.; Wahid, R.A. Influences of Media Richness on Instagram towards Consumer Purchase Intention: The Mediating Effect of Brand Equity. Int. J. Innov. 2020, 10, 357-367. [CrossRef]

54. Agustiansyah, Z.; Mardhiyah, D. The influence of endorser credibility, brand credibility, and brand equity on the purchase In Advances in Business, Management and Entrepreneurship, Proceedings of the 3rd Global Conference on Business Management $\mathcal{E}$ Entrepreneurship (GC-BME 3), Bandung, Indonesia, 8 August 2018, 1st ed.; Hurriyati, R., Tjahjono, B., Yamamoto, I., Rahayu, A., Abdullah, A.G., Danuwijaya, A.A., Eds.; CRC Press: London, UK, 2020; pp. 221-225. [CrossRef]

55. Seo, E.-J.; Park, J.-W. A Study on the Effects of Social Media Marketing Activities on Brand Equity and Customer Response in the Airline Industry. J. Air Transp. Manag. 2018, 66, 36-41. [CrossRef]

56. Rambocas, M.; Kirpalani, V.M.; Simms, E. Brand Equity and Customer Behavioral Intentions: A Mediated Moderated Model. Int. J. Bank Mark. 2018, 36, 19-40. [CrossRef]

57. Parra-López, E.; Bulchand-Gidumal, J.; Gutiérrez-Taño, D.; Díaz-Armas, R. Intentions to Use Social Media in Organizing and Taking Vacation Trips. Comput. Hum. Behav. 2011, 27, 640-654. [CrossRef]

58. Li, S.K.; Huang, X.I.; Jiang, Y. When and Why Are Consumers Reluctant to Seek For Help When They Encounter Difficulties in Using the Products? The Role of Consumption Type. In NA-Advances in Consumer Research; Argo, J., Lowrey, T.M., Schau, H.J., Eds.; Association for Consumer Research: Duluth, MN, USA, 2020; Volume 48, pp. 500-501.

59. Kaufman, J.C.; Pumaccahua, T.T.; Holt, R.E. Personality and Creativity in Realistic, Investigative, Artistic, Social, and Enterprising College Majors. Pers. Individ. Differ. 2013, 54, 913-917. [CrossRef]

60. Doumen, M.; Pazmino, S.; Bertrand, D.; on behalf of the TapERA study group. POS0266-HPR Patient-Perceived Aspects of Ra Flare Evolve Over Time, As Reflected by the Flare-Ra Questionnaire: Post-Hoc Analysis of Tapera. ARD 2021, 80, 356. [CrossRef]

61. Jorgenson, D.J.; Landry, E.J.L.; Lysak, K.J. Family physician perceptions of a medication assessment clinic located within a pharmacy school. Can. Fam. Physician 2017, 63, 512-517. 
62. Lajevardi, N.; Abrajano, M. How Negative Sentiment toward Muslim Americans Predicts Support for Trump in the 2016 Presidential Election. J. Politics 2019, 81, 296-302. [CrossRef]

63. Nicolau, J.L.; Guix, M.; Hernandez-Maskivker, G.; Molenkamp, N. Millennials' Willingness to Pay for Green Restaurants. Int. J. Hosp. Manag. 2020, 90, 102601. [CrossRef]

64. Friedman, D.B.; Gibson, A.; Torres, W.; Irizarry, J.; Rodriguez, J.; Tang, W.; Kannaley, K. Increasing Community Awareness about Alzheimer's Disease in Puerto Rico Through Coffee Shop Education and Social Media. Community Health 2016, 41, 1006-1012. [CrossRef]

65. Willits, F.K.; Theodori, G.L.; Luloff, A.E. Another Look at Likert Scales. JRSS 2016, 31, 126-139.

66. Leung, S.-O. A Comparison of Psychometric Properties and Normality in 4-, 5-, 6-, and 11-Point Likert Scales. J. Soc. Serv. Res. 2011, 37, 412-421. [CrossRef]

67. Hahs-Vaughn, D.L. Applied Multivariate Statistical Concepts, 1st ed.; Routledge: New York, NY, USA, 2017. [CrossRef]

68. Hair, J.F.; Black, W.C.; Babin, B.J.; Anderson, R.E. Multivariate Data Analysis, 7th ed.; Pearson Education Limited: Harlow, UK, 2014.

69. Garson, G.D. Testing Statistical Assumptions; Blue Book Series; North Carolina State University School of Public and International Affairs: Raleigh, NC, USA; Statistical Associates Publishing: Asheboro, NC, USA, 2012.

70. Burdenski, T.K. Evaluating Univariate, Bivariate and Multivariate Normality Using Graphical Procedures. In Proceedings of the Annual Meeting of The American Educational Research Association, New Orleans, LA, USA, 24-28 April 2000.

71. Chin, W. The Partial Least Squares Approach to Structural Equation Modeling. In Modern Methods for Business Research; Marcoulides, A., Ed.; Lawrence Erlbaum Associates: Mahwah, NJ, USA; London, UK, 1998; pp. 295-336.

72. Urbach, N.; Ahlemann, F. Structural Equation Modeling in Information Systems Research Using Partial Least Squares. J. Inf. Technol. Theor. Applic. 2010, 11, 5-40.

73. Cronbach, L.J. Coefficient Alpha and the Internal Structure of Tests. Psychometrika 1951, 16, 297-334. [CrossRef]

74. Werts, C.E.; Linn, R.L.; Joreskog, K.G. Intraclass Reliability Estimates: Testing Structural Assumptions. Educ. Psychol. Meas. 1974, 34, 25-33. [CrossRef]

75. Kock, N. Common Method Bias in PLS-SEM: A Full Collinearity Assessment Approach. Int. J. e-Collab. 2015, 11, 1-10. [CrossRef]

76. Sobel, M.E. Asymptotic Confidence Intervals for Indirect Effects in Structural Equation Models. Sociol. Methodol. 1982, 13, 290-312. [CrossRef]

77. Zadeh, A.H.; Zolfagharian, M.; Hofacker, C.F. Customer-Customer Value Co-Creation in Social Media: Conceptualization and Antecedents. J. Strateg. Mark. 2019, 27, 283-302. [CrossRef]

78. Keller, K.L. Understanding Brands, Branding and Brand Equity. J. Interact. Mark. 2003, 5, 7-20. [CrossRef]

79. Beverland, M. Brand Management: Co-Creating Meaningful Brands; SAGE: Los Angeles, CA, USA, 2018.

80. Slaton, K.; Testa, D.; Bakhshian, S.; Fiore, A.M. The Small, Inventory Free Retail Format: The Impact on Consumer-Based Brand Equity and Purchase Behavior. J. Retail. Consum. Serv. 2020, 57, 102246. [CrossRef] 